\title{
The Effects of Central Government Transfers on Local Revenue Collection by Urban Local Governments in Uganda: A Case of Selected Municipal Councils
}

\author{
Yeko Mwanga ${ }^{1,}$, , Fred Maniragaba ${ }^{1}$, Paulino Ariho ${ }^{2}$ \\ ${ }^{1}$ School of Statistics and Planning, College of Business and Management Sciences, Makerere University, Kampala, Uganda \\ ${ }^{2}$ Department of Sociology and Social Administration, Kyambogo University, Kampala, Uganda \\ Email address: \\ yekomwanga@gmail.com (Y. Mwanga), arihopaulino@yahoo.com (F. Maniragaba), fmaniragaba@gmail.com (P. Ariho) \\ *Corresponding author
}

To cite this article:

Yeko Mwanga, Fred Maniragaba, Paulino Ariho. The Effects of Central Government Transfers on Local Revenue Collection by Urban Local Governments in Uganda: A Case of Selected Municipal Councils. International Journal of Business and Economics Research.

Vol. 9, No. 5, 2020, pp. 335-341. doi: 10.11648/j.ijber.20200905.16

Received: August 10, 2020; Accepted: August 22, 2020; Published: September 24, 2020

\begin{abstract}
Government of Uganda is undertaking reforms to improve on the funding levels and modalities of local governments but is faced with a limited budget to fund both the central government and decentralized functions. Less is known about the effect of central government transfers to local revenue collection especially in the context of decentralization in Uganda. We assessed the effects of central government transfers on local revenue generation by municipalities in Uganda by analyzing the trends of central government transfers and locally generated revenues by the municipal councils and assessing the effects of central government transfers on own local revenue generation. Our study focused on municipalities that have been in existence since introduction of decentralization policy and some of these have recently been upgraded into cities. Time series data covering the selected municipalities were obtained from the Local Government Finance Commission. The dataset comprised of locally generated revenue and central government transfers for 13 old municipal councils. The data was in Excel and it had to be exported to E-Views statistical software for further analysis using the fixed effects regression model. Our findings indicate that over the period 2002 to 2017, both central government grants and local revenue generation grew exponentially. We find that increased central government grants contributed to a decline in locally generated revenue and this partly attributable to too much reliance of the local governments on central grants. The results showed that the lagged total central government grants had a significant negative effect on the locally generated revenue. Government should factor in the allocation formula for central government grants to the local revenue performance to serve as an incentive for the municipal councils to raise own local revenue.
\end{abstract}

Keywords: Central Government Transfers, Locally Generated Revenue, Urban Local Governments, Fixed Effects Regression

\section{Introduction}

It is widely considered that decentralization contributes to effective service delivery because of the closeness of decision making to the local constituents [1,2]. However, it is difficult to find systematic evidence of decentralization outcomes [3]. Due to decentralization in developing countries, there are generally limited revenue sources to finance service delivery by local governments hence the local governments rely heavily on central governments transfers [4]. For instance, in Mali, the low level of revenue collected by local governments drove further revenues transferred by the central government to local governments [5]. In Indonesia, the special purpose capital grant was significant in simulating local public capital spending [6]. The government funds transfer system in many developing countries contributes to local government imbalances and it makes it very difficult for them to meet the needs of the 
residents [7]. A study done in Brazil found that the state and municipal revenue-sharing funds did not distribute revenues fairly and equitably and revenue-sharing was conducive to fiscal mismanagement [8]. According to another study conducted in Brazil, larger cities are more likely to manage revenue and expenditure better than smaller cities [9]. The low level of revenue collection by local governments may also be linked to inadequate capacity to design and implement local taxation systems. In Tanzania, it was revealed that the capacity of local governments to design and collect revenues was very weak and thus there was need for external support in the design of local government tax systems [10].

Revenues that local governments receive from central governments have influences on local revenue collections but are also affected by external factors as well as local revenue generated by the local governments. Generally, studies conducted in developed and developing countries revealed mixed findings on the effect of intergovernmental transfers on the local revenue generation. Masaki and Brun \& Sanogo in their work found a positive relationship between the central government transfers and local government revenue [11] and [12]. Brun \& Sanogo found a positive relationship between the central government transfers and local government revenue generation in a study done in Cote D'Ivoire and Masaki found similar results for Tanzania $[11,12]$. In Benin, a study by Caldeiraa and Rota-graziosi revealed that grants from central government had a positive impact on local source revenue but this effect was contingent on a minimum level of wealth of the local government [13]. Relatedly, in China, Wang et al. noted that the decentralized fiscal system over the period 1986-1993 had a positive impact on the tax share [14]. On the other hand, a study conducted by Mogues and Benin in Ghana revealed that intergovernmental grants discourage rather than encourage locally generated revenues and funds [15].

In Uganda, decentralization policy is considered to be key in national development because it empowers the citizens to participate in planning, budgeting and implementation and most especially decide on their priorities. According to the Government of Uganda, the national and local priorities are financed through central government grants and the own local revenues [16]. The Auditor General confirmed that local governments rely majorly on the intergovernmental fiscal transfers to finance their budgets [17]. This trend is not healthy since the greatest share of these central grants are for earmarked activities and the local governments have no discretion to reallocate these funds to their priorities. Indeed, the municipal councils and local governments generally have full authority to budget and utilize their own locally generated revenue. The Government of Uganda had a fairly strong decentralization system at independence in 1962 which collapsed due to unfavorable political climate. Decentralization policy was reintroduced in 1993 starting with the formulation of a legal and regulatory framework through the adoption of the Local Governments (Resistance Councils) Statute. The statute provided for decentralization of functions, powers and services to local governments, which enabled constituents to participate more in decisionmaking on matters of planning, budgeting and financing of their priorities. The 1995 Constitution entrenched further decentralization by clearly spelling out the decentralized functions and services to local governments and those that were retained by central government. The Government of Uganda enacted the Local Government Act of 1997 to further clarify on matters of operationalization of decentralization in the country [16]. The local government structure in Uganda comprises of higher local governments and lower local governments. Nakayi in her study described the diferent levels of government in the country, districts and municipalities form the higher local governments while the sub-county councils, town councils and division councils form the lower local governments [18]. There are seven city councils which were recently $\left(1^{\text {st }}\right.$ July 2020) upgraded from municipalities and 35 municipal councils of which the majority were created over the last decade. The old municipalities were 13 spread across the country in the four regions: eastern, northern, central and western. Luwemba pointed out that according to the law the local governments are empowered to plan and implement their budgets [19].

The municipal councils and generally local governments' functions are financed mainly through central government grants and own local revenue. The Constitution spelt out three types of grants, namely; conditional grants, unconditional grants and equalization grants. The unconditional grants are minimum funds intended for financing decentralized services, it currently covers mostly salaries and wages. Whereas conditional grants are meant for national priority areas agreed upon between the central government and the local governments, equalization grant finances local governments deemed to be lagging behind the national average standard in service delivery.

Table 1. Local Government Revenue in 2018/19 (Millions).

\begin{tabular}{lllll}
\hline Revenue Source & District Local Government & \% & Municipal Council Government & \% \\
\hline Own local revenue & $76,084.24$ & 2.2 & $77,981.43$ & 16.6 \\
Discretionary government transfers & $461,076.57$ & 13.4 & $56,223.12$ & 11.9 \\
Conditional government transfers & $2,244,290.49$ & 65.3 & $267,252.75$ & 56.7 \\
Other government transfers & $482,957.15$ & 14.0 & $68,529.45$ & 14.5 \\
Donor funding & $173,556.43$ & 5.0 & $1,075.50$ & 0.2 \\
Total & $3,437,964.87$ & 100.0 & $471,062.25$ & 100.0 \\
\hline
\end{tabular}

Source: Local Government Finance Commission, Uganda 
Table 1 shows that in $2018 / 19$, central government transfers accounted for about $93 \%$ and $83 \%$ of the total revenue for the district and municipal councils respectively.

In the last three years, the Government of Uganda has embarked on fiscal reforms which comprised of the consolidation of the equalization grants with Local Government Management Service Delivery Program, Peace Recovery and Development Plan; Luwero Rewenzori Development Program and Uganda Support to Municipal Infrastructure Development. The consolidated grant was renamed discretional development equalization grant.

According to the Government of Uganda the local sources of revenue for urban councils shall include: local service tax, local hotel tax, property tax, building plan fees, rents from urban markets, market dues, taxi/bus park fees, licenses and permits, land fees, business registration and advertisement fees among others [16]. Adequate financing of the local governments is vital for realization of the national development goals as well as the local objectives. The National Development Plan II underscores the importance of decentralization in the nation's quest for development. In addition, the Government is undertaking reforms to improve on the funding levels and modalities of local governments. The Government is faced with a limited budget to fund both the central government and decentralized functions. This study determined the effect of central government grants on locally generated revenue.

Uganda has had a number of fiscal reforms since decentralization commenced. The reforms were intended to reduce on the number of grants and ensure effectiveness of the management of these grants. However, a new trend has emerged where the central government through Uganda Revenue Authority has taken over the collection of some previously decentralized sources of revenue such as collection bus/taxi park with no clear guideline on how much of these funds shall be remitted to the local government. In Uganda, less is known about the effect of central government transfers to local revenue collection especially in the context of decentralization. The main objective of the study was to assess the effects of central government transfers on local revenue generation by municipalities in Uganda by analyzing the trends of central government transfers and locally generated revenues by the municipal councils and assessing the effects of central government transfers on own local revenue generation. In this study, we hypothesize that; Central government transfers and local governments revenue are not trended; and that there is no effect of central government transfers on own local revenue generation.

\section{Data Description and Methodology}

\subsection{Data Description}

There are currently 42 municipal councils in the country and most of which were created over the last decade. Our study focused on municipalities that have been in existence since introduction of decentralization policy and some of these have recently been upgraded into cities. The selected municipal councils were: Arua, Gulu, Lira, Mbarara, Tororo, Jinja, Entebbe, Masaka, Mbale, Fort Portal, Kabale, Soroti and Moroto. These municipal councils are spread across the four regions of the country, namely; Central, Eastern, Northern and Western. These are some of the biggest municipalities in Uganda.

Time series data covering the selected municipalities were obtained from the Local Government Finance Commission. The dataset comprised of locally generated revenue and central government transfers for 13 old municipal councils. The data was in Excel and it had to be exported to E-Views statistical software for further analysis.

\subsection{Methodology}

The model specification is as follows:

$$
L R_{i t}=\beta_{0}+\beta_{1} C G_{i t}+\beta_{2} C G_{i t-1}+\beta_{3} L R_{i t-1}+u_{i}+v_{t}+e_{i t}
$$

Where:

LR represents the municipal locally generated revenue, $\mathrm{CG}$ is the central government grants (conditional grants, unconditional grants, and other central transfers) to individual municipalities, $u_{i}$ represents the municipal fixed effects while $v_{t}$ represents the year fixed effects, $e_{i t}$ is the random error term, $\mathrm{i}$ is the municipality, $\mathrm{t}$ is the is the time.

The fixed effects regression model was estimated and tested for reliability using the Hausman test and Chow test to select the best of the three models i.e. common effect, fixed effects and random effect.

\section{Results \& Discussion}

This section presents empirical results from the estimation of equation 1 for the 13 municipal councils and over a period of thirteen years (2002 to 2017).

Trends of the Central Government Grants and Local Revenue

The local governments are funded mainly through central government grants, locally generated revenue and donations. Figure 1 shows that central government grants to selected municipalities from 2002 to 2017 grew exponentially. The municipal councils which received the highest grants are some of those soon to be upgraded into cities such as Mbarara and Fort Portal municipalities. The municipalities to be upgraded are considered the largest in terms of population and with the highest local revenue potential.

The findings in Figure 2 reveal that generally the municipalities to be upgraded into cities had the highest municipal local revenue collections. Jinja and Mbale 
Municipal Councils collections realized the highest local revenue collections over the 15 years. Bahl in a partly related finding was reported in a study conducted in Brazil in which larger cities were more likely to generate and manage revenue and expenditure better than smaller cities [9].

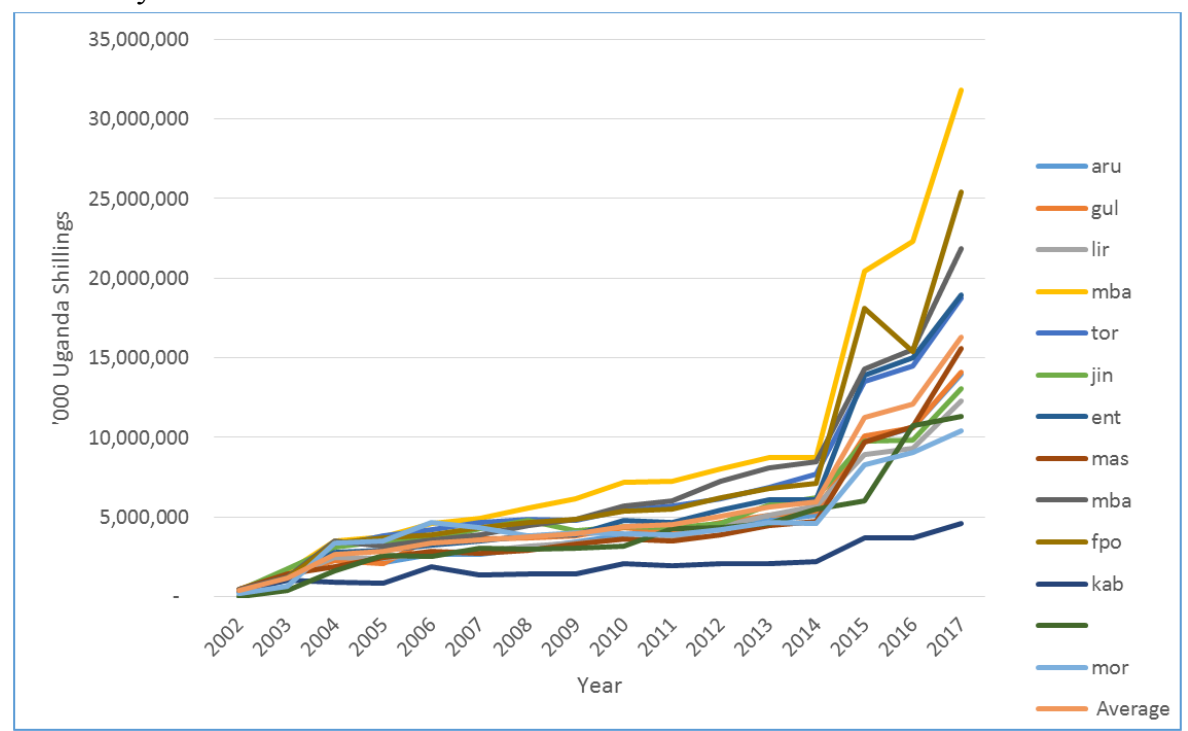

Figure 1. Central Government Grants to Selected Municipal Councils.

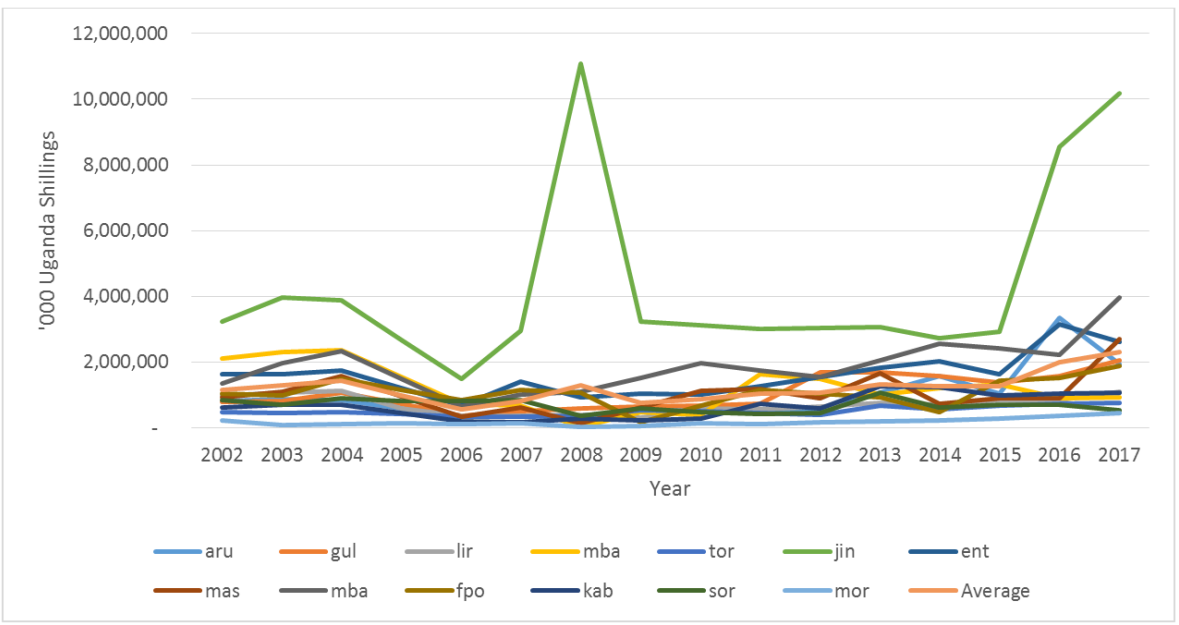

Figure 2. Own Local Revenue for Selected Municipal Councils.

The results in Figure 3 show that central government grants and local revenue collections for the 13 selected municipal councils depicted exponential growth trends during the period 2002 to 2017.

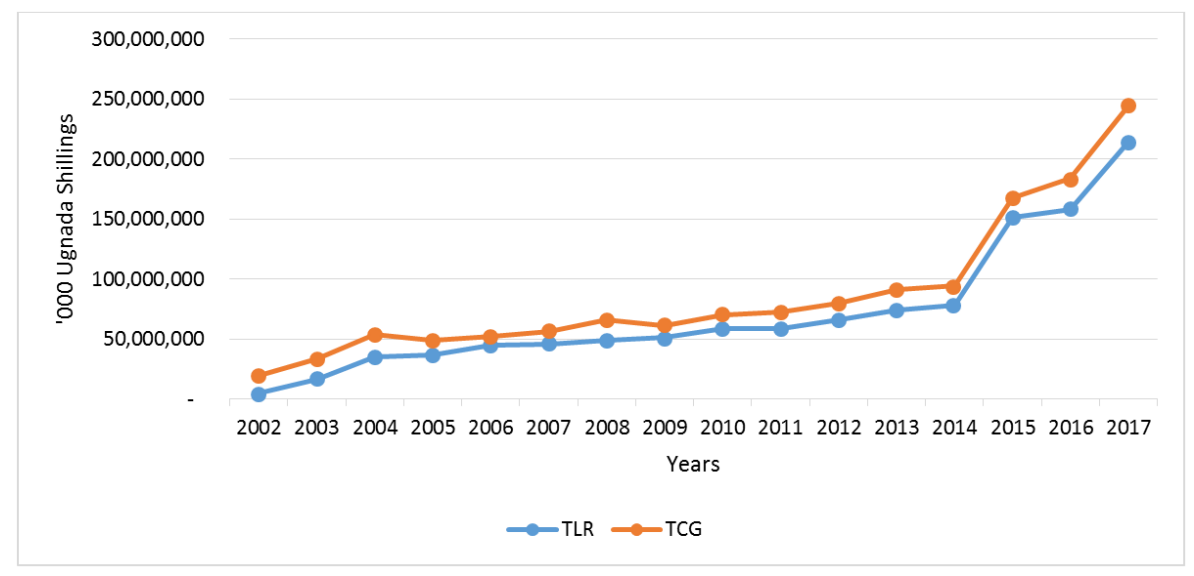

Figure 3. Total Central Government Grants (TCG) and Total Local Revenue (TLR) for 13 Municipalities. 
Table 2. Test cross-section fixed effects (Chow Test).

\begin{tabular}{llll}
\hline Chow Test & Statistics & d. f & Probability \\
\hline Cross-section F & 4.982 & 12,179 & 0.00 \\
Cross-section fixed effects $x^{2}$ & 56.197 & 12 & 0.00 \\
\hline
\end{tabular}

In the selection of the appropriate fixed effects model some tests were performed. Table 2 shows the computed cross section fixed effects (chow) test $\mathrm{p}$ which was less than 0.05 , hence the common effect model was rejected in favor of the fixed effects model.

The Hausman specification test was also performed to determine whether the fixed effects model or random effects model was more reliable for estimation. Table 3 presents the computed $\mathrm{p}$ for the Hausman test which was less than 0.05 , hence the random effects model was rejected in favor of the fixed effects model.

Table 3. Test for Cross-section random (Hausman Test).

\begin{tabular}{llll}
\hline Hausman test & Statistics & d. f & Probability \\
\hline Cross-section random effects $\chi^{2}$ & 59.274 & 3 & 0.00 \\
\hline
\end{tabular}

Table 4. Estimates for the fixed effects model (2002 - 2017).

\begin{tabular}{|c|c|c|c|c|c|c|}
\hline Dependent Variable & \multicolumn{6}{|c|}{ Log Locally Generated Revenue } \\
\hline Independent Variables (1) & \multicolumn{2}{|l|}{ (2) } & \multicolumn{4}{|l|}{ (32) } \\
\hline Log Lag Locally Generated Revenue & \multicolumn{2}{|c|}{$0.6142 * *(0.0471)$} & \multicolumn{4}{|c|}{$0.2071 * *(0.0664)$} \\
\hline Log Total Central Government Grants) & \multicolumn{2}{|c|}{$0.1958 * *(0.0857)$} & \multicolumn{4}{|c|}{$0.1243(0799)$} \\
\hline Log Lag Total Central Government Grants & \multicolumn{2}{|c|}{$-0.1253 * *(0.0629)$} & \multicolumn{2}{|c|}{$-0.1112 * *(0.0565)$} & & \\
\hline \multirow[t]{2}{*}{ Constant } & \multicolumn{2}{|c|}{192954.3} & \multicolumn{2}{|c|}{$948493.9 * *$} & & \\
\hline & \multicolumn{2}{|c|}{$(\mathbf{1 7 5 7 5 4 . 1 )}$} & \multicolumn{2}{|c|}{$(230392.2)$} & & \\
\hline \multirow[t]{16}{*}{ Fixed Effects (municipal and year dummies) } & \multicolumn{2}{|l|}{ Year } & \multicolumn{2}{|l|}{ Year } & \multicolumn{2}{|c|}{ Municipal } \\
\hline & 2002 & 264517.2 & 2002 & 39763.5 & ARU & -203150.0 \\
\hline & 2003 & 304258.0 & 2003 & 184356.0 & GUL & -134849.6 \\
\hline & 2004 & 453624.7 & 2004 & 254459.8 & LIR & -374939.3 \\
\hline & 2005 & 325686.8 & 2005 & -47998.56 & MBR & 167294.0 \\
\hline & 2006 & -358337.4 & 2006 & -587515.2 & TOR & -499811.4 \\
\hline & 2007 & -388904.3 & 2007 & -421359.4 & JIN & 2105849 . \\
\hline & 2008 & 374866.9 & 2008 & 147176.4 & ENT & 307941.7 \\
\hline & 2009 & -172905.8 & 2009 & -350146.8 & MAS & -185315.1 \\
\hline & 2010 & -263968.4 & 2010 & -335409.9 & MBA & 469144.1 \\
\hline & 2011 & -65808.42 & 2011 & -127353.5 & FPT & -52224.91 \\
\hline & 2012 & -207818.8 & 2012 & -138954.4 & $\mathrm{KAB}$ & -441860.1 \\
\hline & 2013 & 8056.251 & 2013 & 85156.9 & SOR & -356536.0 \\
\hline & 2014 & 563183.9 & 2014 & 590831.4 & MOR & -801542.3 \\
\hline & 2015 & -906304.3 & 2015 & -187299.3 & & \\
\hline & 2016 & 69853.40 & 2016 & 894293.2 & & \\
\hline Municipal Effects & No & & Yes & & & \\
\hline Year Effects & Yes & & Yes & & & \\
\hline Observations & 195 & & 195 & & & \\
\hline $\mathrm{R}^{2}$ & 0.492 & & 0.605 & & & \\
\hline Number of Municipalities & 13 & & 13 & & & \\
\hline
\end{tabular}

Note: Standard errors are in parenthesis and $* * \mathrm{p}<0.05$.

The fixed effects for period/year regression results are presented in Table 4, column 2 while the fixed effects of both period/year and municipal councils are given in column 3 . The lagged total central government grants to municipal councils is significant and negative in both equations implying that the previous year's central government grants lead to a decrease in locally generated revenues. After controlling for both municipality and period/years, an increase of 1,000 shillings in the central government grants leads to a decrease of 0.11 shillings in municipal locally generated revenue. The effect of current central government grants on locally generated revenues appears positive but not significant when the fixed effect is controlled for both the period/year and municipal effects. Additionally, the $\mathrm{R}^{2}$ is higher once the fixed effects model is controlled for both the effects.

All local governments rely heavily on the central government transfers for funding of their budgets. On average about $90 \%$ of the district budgets are financed by the central government grants while for municipalities it's about $70 \%$. Contrary to the findings of Masaki in Tanzania, increased central government grants contribute to a decline in locally generated revenue possibly because of too much reliance of the local governments on central grants for funding their budgets [11]. The municipal councils also lack proper registers of tax payers and taxable properties. Furthermore, there are no good monitoring systems for revenue collection leading to possible leakages. Possibly as a 
result, the central government has taken over the collection of some municipal taxes/dues which may have demotivated the municipal councils since those sources were the most productive. The central government has taken over the collection of bus/taxi parks and market dues.

\section{Conclusion}

The local revenue collections are very important for budget financing because the municipal councils have discretion in their budgeting and utilization. Most of the central government grants are conditional which implies that they are intended for national priorities. The central government grants are aimed at ensuring equity and provision for spillover effects. Our findings indicate that over the period 2002 to 2017 , both central government grants and local revenue generation grew exponentially. We find that increased central government grants contributed to a decline in locally generated revenue and this partly attributable to too much reliance of the local governments on central grants

The Government should factor in the allocation formula the local revenue performance as an incentive for the municipal councils to raise locally generated revenue. Even for the centrally collected municipal revenue in the sharing arrangement performance should be factored in so that municipal authorities support the central government efforts of collecting more revenue.

The Government should support municipal councils and local governments generally in terms of registration of tax payers \& properties, setting up monitoring tax/dues collection \& compliance system, capacity building of staff with requisite skills to enable them realize more own locally generated revenue. The transfer of some municipal revenue sources to the central government serves to weaken the local governments because they are denied an opportunity to build capacity in order to improve efficiency and effectiveness in revenue collection and service delivery.

\section{Appendix}

Table 5. Results of fixed effects (year dummies) panel model (2002 - 2016).

\begin{tabular}{|c|c|c|c|c|}
\hline \multicolumn{5}{|c|}{ Method: Panel Least Squares } \\
\hline \multicolumn{5}{|c|}{ Date: 04/07/20 Time: 15:17 } \\
\hline \multicolumn{5}{|c|}{ Sample (adjusted): 20022016} \\
\hline \multicolumn{5}{|l|}{ Periods included: 15} \\
\hline \multicolumn{5}{|c|}{ Cross-sections included: $\mathbf{1 3}$} \\
\hline \multicolumn{5}{|c|}{ Total panel (balanced) observations: 195} \\
\hline Variable & Coefficient & Std. Error & t-Statistic & Prob. \\
\hline $\mathrm{C}$ & 192954.3 & 175754.1 & 1.097865 & 0.2738 \\
\hline LR (1) & 0.614155 & 0.047141 & 13.02818 & 0.0000 \\
\hline CG & 0.195782 & 0.085743 & 2.283362 & 0.0236 \\
\hline CG (1) & $\begin{array}{l}-0.125270 \\
\text { Effects Spec }\end{array}$ & 0.062928 & -1.990696 & 0.0481 \\
\hline \multicolumn{5}{|c|}{ Period fixed (dummy variables) } \\
\hline R-squared & 0.536203 & Mean depe & & 1144084. \\
\hline Adjusted R-squared & 0.491658 & S. D. deper & & 1201113. \\
\hline S. E. of regression & 856370.9 & Akaike inf & & 30.24656 \\
\hline Sum squared resid & $1.30 \mathrm{E}+14$ & Schwarz cr & & 30.54868 \\
\hline Log likelihood & -2931.040 & Hannan-Q & & 30.36889 \\
\hline F-statistic & 12.03723 & Durbin-Wa & & 2.438248 \\
\hline Prob (F-statistic) & 0.000000 & & & \\
\hline
\end{tabular}

Table 6. Results of fixed effects (municipal and year dummies) panel model (2002 - 2016).

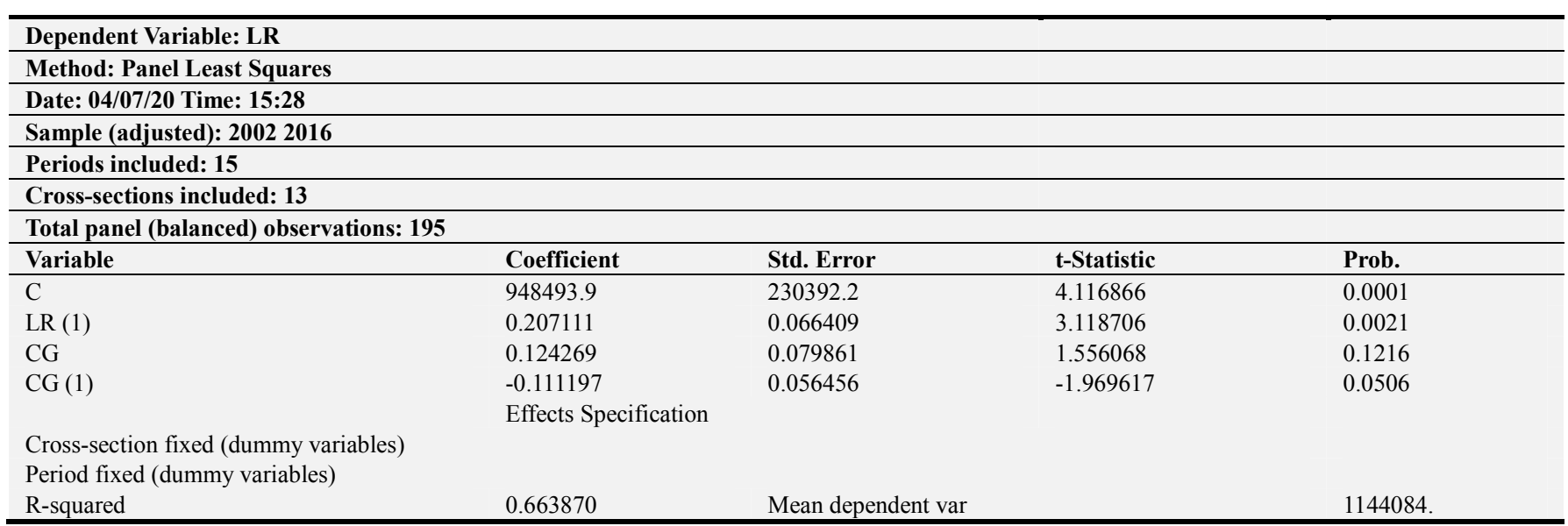




\begin{tabular}{|c|c|c|c|c|}
\hline \multicolumn{5}{|c|}{ Dependent Variable: LR } \\
\hline \multicolumn{5}{|c|}{ Method: Panel Least Squares } \\
\hline \multicolumn{5}{|c|}{ Date: 04/07/20 Time: $15: 28$} \\
\hline \multicolumn{5}{|c|}{ Sample (adjusted): 20022016} \\
\hline \multicolumn{5}{|c|}{ Periods included: 15} \\
\hline \multicolumn{5}{|c|}{ Cross-sections included: 13} \\
\hline \multicolumn{5}{|c|}{ Total panel (balanced) observations: 195} \\
\hline Variable & Coefficient & Std. Error & t-Statistic & Prob. \\
\hline Adjusted R-squared & 0.604792 & S. D. dependent var & & 1201113. \\
\hline S. E. of regression & 755086.5 & Akaike info criterion & & 30.04769 \\
\hline Sum squared resid & $9.41 \mathrm{E}+13$ & Schwarz criterion & & 30.55123 \\
\hline Log likelihood & -2899.650 & Hannan-Quinn criter. & & 30.25157 \\
\hline F-statistic & 11.23727 & Durbin-Watson stat & & 2.238025 \\
\hline Prob (F-statistic) & 0.000000 & & & \\
\hline
\end{tabular}

\section{References}

[1] Klugman J. Decentralisation: A Survey of Literature from a Human Development Perspective. SSRN Electron J 2013.

[2] United Nations Development Programme. Human Development Report: New Dimension of Human Security. 1994.

[3] Crook RC. Decentralisation and poverty reduction in Africa: the politics of local-central relations. Public Adm Dev 2003; 23: 77-88.

[4] Bahl R. "Intergovernmental Transfers in Developing and Transition Countries: Principles and Practice. Washington DC: 2000 .

[5] Sanoh A. Rainfall shocks, local revenues, and intergovernmental transfer in mali. World Dev 2015; 66: 35970 .

[6] Lewis B. Local government capital spending in Indonesia: Impact of intergovernmental fiscal transfers. Public Budg Financ 2013; 33: 76-94.

[7] Shar A. Theory and Practice of Intergovernmental Transfers. Reforming China's Public Finances 1995: 215-34.

[8] Shah A. The New Fiscal Federalism in Brazil 1991; 124.

[9] Gomes RC, Alfinito S, Albuquerque PHM. Analyzing local government financial performance: evidence from Brazilian municipalities 2005-2008. Rev Adm Contemp 2013; 17: 704 19.

[10] Fjeldstad O-HH, Semboja J. Dilemmas of Fiscal Decentralisation: A Study of Local Government Taxation in Tanzania. Forum Dev Stud 2000; 27: 7-41.

[11] Masaki T. The impact of intergovernmental transfers on local revenue generation in Sub-Saharan Africa: Evidence from Tanzania. World Dev 2018; 106: 173-86.

[12] Brun E-F, Sanogo T. Effect of central transfers on municipalities' own revenue mobilization: Do conflict and local revenue management matter? 2017.

[13] Caldeiraa E, Rota-graziosi G. The crowding-in effect of simple unconditional central grants on local own-source revenue: The case of Benin. J Afr Econ 2014; 23: 361-87.

[14] Wang Q, Shen C, Zou H. Local government tax effort in China: an analysis of provincial tax performance. Banq Données Doc REGARDS 2009.

[15] Mogues T, Benin S. Do External Grants to District Governments Discourage Own Revenue Generation? A Look at Local Public Finance Dynamics in Ghana. World Dev 2012; 40: 1054-67.

[16] Government of Uganda. Local Government Act 1997. Kampala, Uganda: 1997.

[17] The Auditor General. Financing of Local Governments in Ugnada Through Central Government Granta and Local Government Revenues. Kampala, Uganda: 2016.

[18] Nakayi R. Local governance in Uganda 2018: 1-38.

[19] Luwemba W. The creation of new cities is a smart move. The New Vision 2020. 